\title{
Comment
}

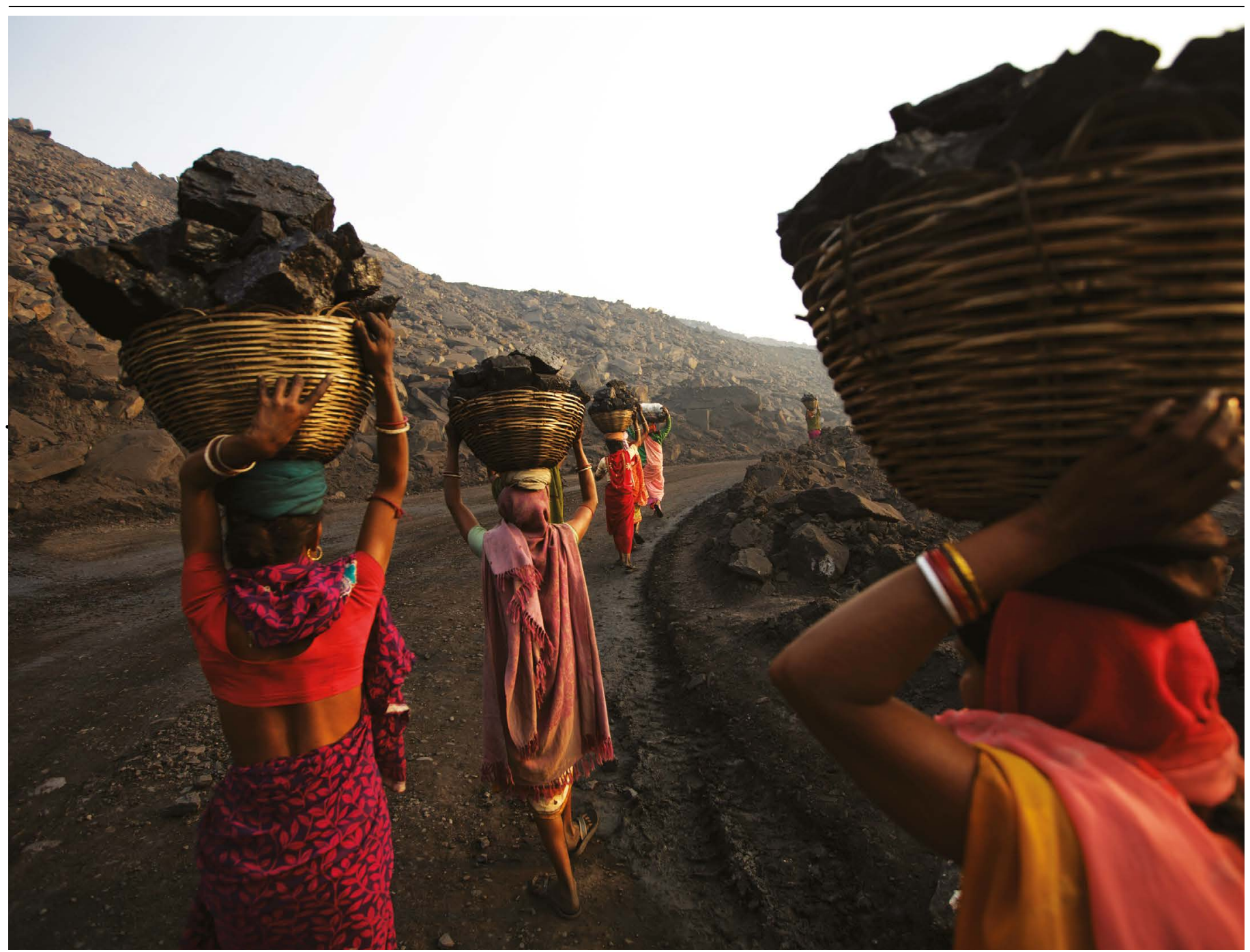

Women carry coal from an open-cast mine in Jharkand state in India.

\section{Emissions: world has four times the work or one-third of the time}

Niklas Höhne, Michel den Elzen, Joeri Rogelj, Bert Metz, Taryn Fransen, Takeshi Kuramochi, Anne Olhoff, Joseph Alcamo, Harald Winkler, Sha Fu, Michiel Schaeffer, Roberto Schaeffer, Glen P. Peters, Simon Maxwell \& Navroz K. Dubash

New synthesis shows what a wasted decade means for the climate pact made in Paris.

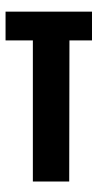

he past decade of political failure on climate change has cost us all dear. It has shrunk the time left for action by two-thirds. In 2010, the world thought it had 30 years to halve global emissions of greenhouse gases. Today, we know that this must happen in ten years to minimize the effects of climate change. Incremental shifts that might once have been sufficient are no longer enough.

The further bad news is that, even taken together, the proposed climate action by all countries is a long way from meeting this requirement. Rather than halving emissions by 2030 , countries' climate proposals will lead toa slight increase. Worse still, individual countries 


\section{Comment}

are not on track to achieve commitments that were insufficient from the outset and are now woefully inadequate.

The better news is that more countries, regions, cities and businesses are implementing the deep, rapid transformations that are urgently required. At scale, these could achieve the collective climate goals that nations agreed in Paris more than four years ago. There are lessons to be learnt from places such as Costa Rica, Shenzhen in China and Copenhagen that have made strides through the use of renewable energy and electrified transport. The United Kingdom (together with 75 other parties) and California have at least set ambitious goals to become carbon neutral, which might send signals to industry even before supporting policies are implemented. Meanwhile, 26 banks have stopped directly financing new coal-fired power plants (see go.nature.com/32uped2).

Much is happening on the ground. The question is how to ramp up these activities fast enough to keep warming to less than $1.5^{\circ} \mathrm{C}$ above pre-industrial levels.

Here we present a snapshot of the extent to which nations' individual pledges are inconsistent with their stated collective goals. We also note some of the pockets of promise. We draw our conclusions from a synthesis of all ten editions of the Emissions Gap Reportproduced by the United Nations Environment Programme $(\mathrm{UNEP})^{1-5}$. Each year for the past decade, this report has examined the difference between what countries have pledged to do individually to reduce greenhouse-gas emissions, and what they need to do collectively to meet agreed temperature goals - the 'gap'.

Our analysis shows that the gap has widened by as much as four times since 2010 . There are three reasons for this. First, global annual greenhouse-gas emissions increased by $14 \%$ between 2008 and 2018 (ref. 6). This means that

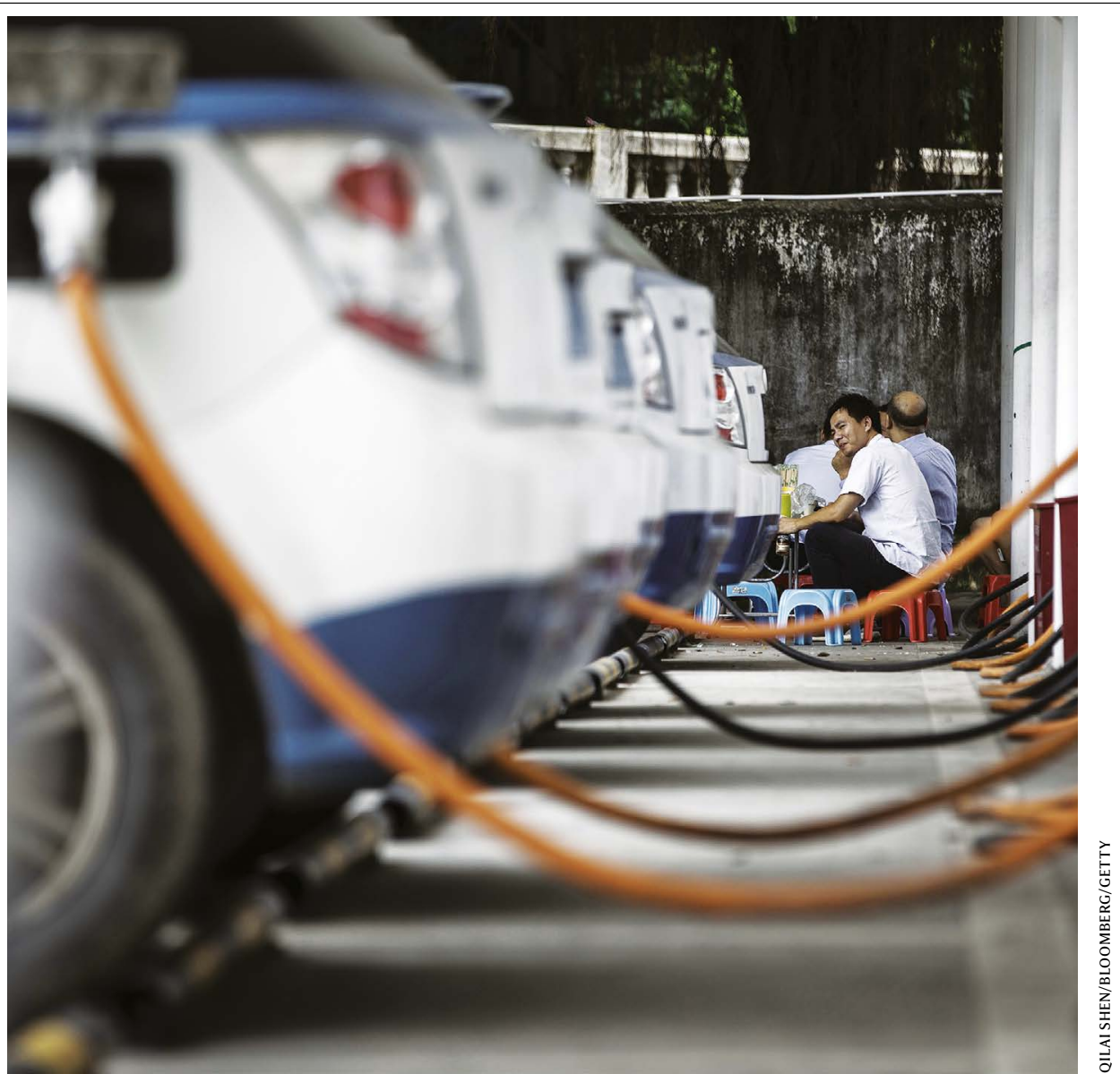

Electric taxis at a charging station in Shenzhen, China.

emissions now have to decline faster than was previously estimated, because it is cumulative emissions that determine the long-term temperature increase. Second, the international community now agrees that it must ensure a lower global temperature rise than it decided ten years ago, because climate risks are better understood. And third, countries' new climate

\section{THE SEVEN TOP EMITTERS}

\begin{tabular}{|c|c|c|}
\hline $\begin{array}{l}\text { Country or region }(2018 \\
\text { emissions in gigatonnes } \\
\left.\mathrm{CO}_{2} \text { equivalent }\right)^{6,13}\end{array}$ & $\begin{array}{l}\text { Change in projected } \\
\text { greenhouse-gas emissions } \\
\text { by } 2030 \text { since } 2015\end{array}$ & Potential reasons \\
\hline China (13.2) & No change & $\begin{array}{l}\text { New climate and energy policies; altered } \\
\text { growth projections. }\end{array}$ \\
\hline United States (6.6) & No change & $\begin{array}{l}\text { Rollback of federal policies works against } \\
\text { price drops in renewables and reductions } \\
\text { in coal use. }\end{array}$ \\
\hline European Union (4.0) & Lower & $\begin{array}{l}\text { Mostly attributable to implementation of } \\
\text { new policies. }\end{array}$ \\
\hline India (3.8) & Slightly lower & Unclear. \\
\hline Russia (2.4) & No change & $\begin{array}{l}\text { No change in policies or growth } \\
\text { projections. }\end{array}$ \\
\hline Indonesia (2.3) & Higher & $\begin{array}{l}\text { Higher emissions projections from } \\
\text { deforestation. }\end{array}$ \\
\hline Brazil (1.6) & Higher & $\begin{array}{l}\text { Higher emissions projections from } \\
\text { deforestation. }\end{array}$ \\
\hline
\end{tabular}

Comparison of the 2015 and 2019 UNEP Emissions Gap Report ${ }^{2,20}$ and other sources ${ }^{21-25}$ provides information about changes in current policy projections for the leading emitters. Uncertainties for each estimate are large. See Supplementary Information for details. pledges have been insufficient.

The tenth anniversary of the report coincides with the 2020 milestone to which countries agreed in Paris. They undertook to communicate or update climate pledges, or 'nationally determined contributions', to the UN Framework Convention on Climate Change conference (COP26) this November in Glasgow, UK. Clearly, the promises must be overhauled and then, crucially, kept - if the yawning gap between 'talk and walk' is going to close by 2030 .

\section{Gap minder}

The scope of the UNEP emissions gap reports has evolved over time, in line with climate policy. So what has changed during the past decade?

In the 2009 Copenhagen accord $^{7}$ and the 2010 Cancun agreement ${ }^{8}$, countries collectively pledged to limit warming to below $2{ }^{\circ} \mathrm{C}$, and 73 countries individually pledged emissions targets for 2020. The 2015 Paris agreement, responding to mounting concern over the impacts of climate change, tightened the collective temperature limit to "well below $2{ }^{\circ} \mathrm{C}$ " and agreed "to pursue efforts to limit the temperature increase to $1.5^{\circ} \mathrm{C}$ " (ref. 9). Under the Paris deal,192 parties individually pledged emissions targets, typically for 2030 (see 'More and faster').

From 2010 to 2014, the gap reports projected 
the likely difference in 2020 between the expected result of countries' pledges and the pathways towards $2{ }^{\circ} \mathrm{C}$. The 2010 report documented a shortfall of $14 \%$. Since 2015 , the reports have forecast the expected shortfall in 2030 between the countries' pledges and progress towards both $1.5^{\circ} \mathrm{C}$ (current shortfall of $55 \%$ ) and $2{ }^{\circ} \mathrm{C}$ (current shortfall of $25 \%$; see 'More and faster'). The report also examines the policies that countries are implementing domestically.

Had serious climate action begun in 2010 , the cuts required to meet the emissions levels for $2{ }^{\circ} \mathrm{C}$ would have been around $2 \%$ per year, on average, up to 2030. Instead, emissions increased. Consequently, the required cuts from 2020 are now more than $7 \%$ per year on average for $1.5^{\circ} \mathrm{C}$ (close to $3 \%$ for $2^{\circ} \mathrm{C}$ ).

The time window for halving global emissions has also narrowed drastically. In 2010, it was 30 years; today, it is 10 years for $1.5^{\circ} \mathrm{C}$ $\left(25\right.$ years for $\left.2^{\circ} \mathrm{C}\right)$. Although many reports, scientists and policymakers continue to discuss rises of $2^{\circ} \mathrm{C}$, it must be emphasized that, in 2018, the Intergovernmental Panel on Climate Change reported that warming of more than $1.5^{\circ} \mathrm{C}$ would be disastrous ${ }^{10}$.

Countries are not even on track to achieve their now plainly inadequate 2015 pledges. Of the G20 countries, seven (Australia, Brazil, Canada, Japan, South Korea, South Africa and the United States) need to implement existing policy or roll out new measures. (The United States has begun the process of withdrawing from the Paris agreement, and will leave in November.) Russia and Turkey have set themselves unambitious targets that they can meet without new policies.

Since 2015, estimated global emissions in 2030 have decreased by only $3 \%$. For the leading seven emitters, 2030 estimates have slightly decreased, flatlined or increased (see 'The seven top emitters').

No single model can predict the future, and such analyses by necessity exclude the most recent developments. Nevertheless, it is clear that, collectively, current policies will not limit global warming to well below $2^{\circ} \mathrm{C}$, let alone $1.5^{\circ} \mathrm{C}$, as agreed in Paris.

Clearly, the annual audit of the emissions gap has not altered poor performance. The gap concept has nonetheless proved useful. The reports and numbers have continuously informed the UN climate summits ${ }^{11}$ and the emissions gap was noted as a serious concern when parties were adopting the Paris agreement ${ }^{9}$.

\section{Transformative action}

Fundamental policy transformations have begun to appear in some sectors, countries, regions, cities and businesses over the past ten years. These innovations seek to achieve the UN's Sustainable Development Goals (SDGs), including climate ones. Slashing emissions now requires 'leaving no one behind'.

\section{MORE AND FASTER}

Insufficient climate action during the past decade means that transformational development pathways are now required to reduce greenhouse-gas emissions on time.

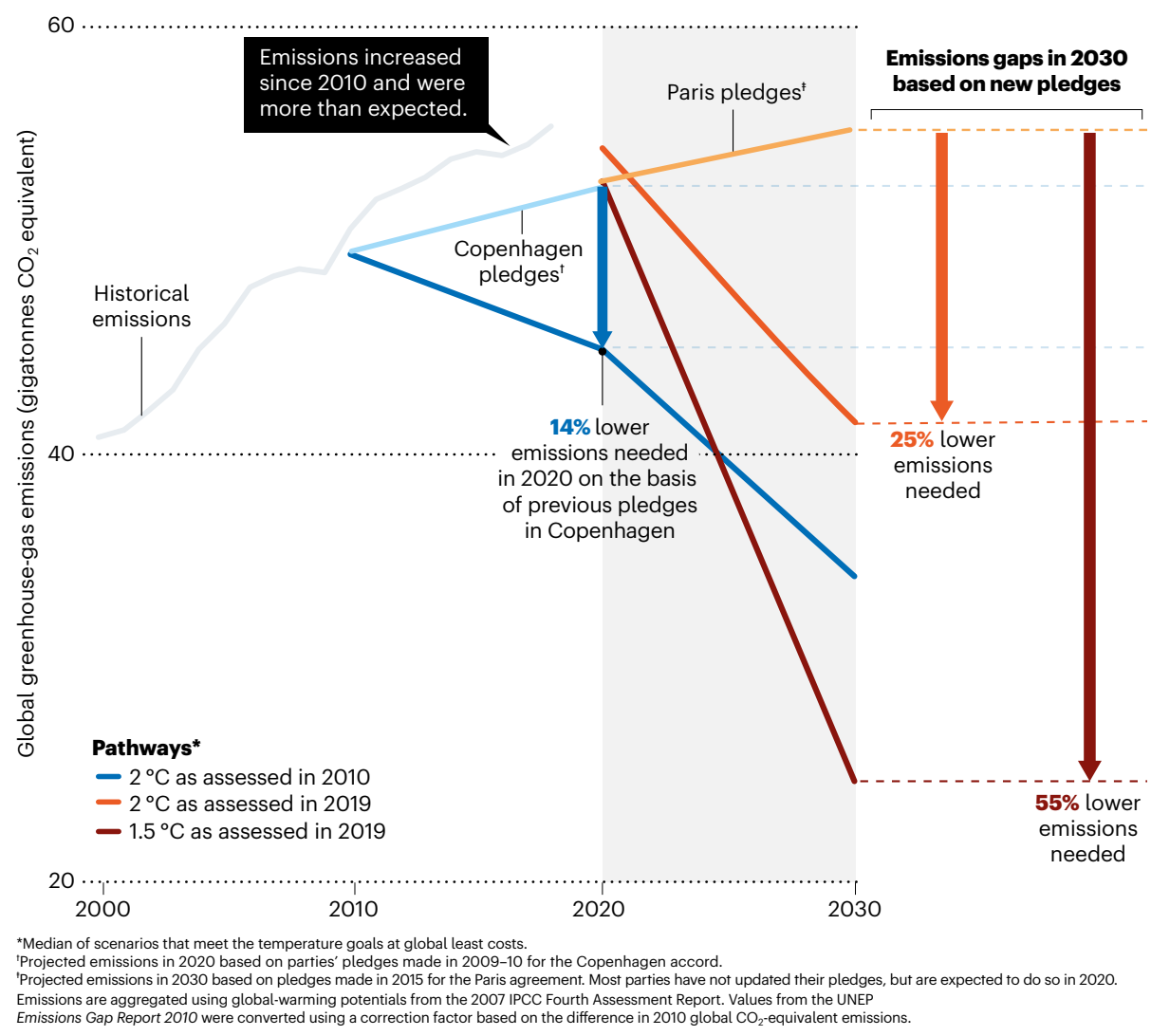

To recognize, monitor and understand these advances, the gap reports have included examples. Some are discussed here.

Ambitious action. Most encouragingly, a wealth of agile nations, regions, cities and businesses have promised or made radical changes since the Paris agreement (see 'Action gap' and Supplementary Information. See also go.nature.com/2t22tth). At the last count, net-zero

\section{“Current policies will not limit global warming to well below $2^{\circ} \mathrm{C}$, let alone $1.5^{\circ} \mathrm{C}$, as agreed in Paris."}

emissions goals have been set or are being considered by 76 countries or regions (the European Union is the largest) and 14 sub-national regions or states (the largest being California); some locations have begun implementation. Together, these places account for about $21 \%$ of global greenhouse-gas emissions ${ }^{12,13}$.

Fifty-three countries and 31 states and regions have explicitly committed to an emissions-free electricity sector. Seven additional countries have done so implicitly by aiming for net-zero greenhouse-gas emissions. Together, these account for around $18 \%$ of global electricity generation ${ }^{14}$. Twenty-one countries, 5 regions and more than 52 cities have committed to make all vehicles emissions-free. Individual examples also exist for sectors in which reaching zero emissions was thought to be difficult, such as heavy industry and aviation. Steel giants ThyssenKrupp in Essen, Germany, and SSAB in Stockholm are aiming for zero-emissions steel production by 2050 and 2045, respectively. The building-materials company Heidelberg Cement, headquartered in Germany, is aiming for zero-emissions cement production by 2050 . For aviation, Norway and Scotland hope to make short-haul and domestic flights zero emissions by 2040.

Renewables. Costs of renewable energy are falling faster than expected ${ }^{15}$. Renewables are currently the cheapest source of new power generation in most of the world. Solar and wind power will be financially more competitive than will existing coal plants by next year ${ }^{15}$. These cost declines, and those of battery storage, are opening up possibilities for large-scale, low-carbon electrification.

Coal consumption. The rise of renewable energy can - must - facilitate a move away from coal. Emerging economies that depend on coal, such as China and India, have begun to address consumption by adjusting the fuel's price, capping its consumption, reducing plans for new coal-fired power plants and supporting renewables. Much more must be done, and quickly - while addressing poverty, energy access and urbanization ${ }^{16-18}$. 


\section{Comment}

UNSDGs. Actions to reduce greenhouse-gas emissions are essential for achieving food security, healthy lives and many other SDGs, as confirmed by a growing body of research ${ }^{10,19}$. For example, renewable energy cuts air pollution, and improves health and energy security compared with fossil fuels.

\section{Closing the gap}

These few success stories must be scaled up and mirrored with progress in every sector. The fact that reductions in greenhouse-gas emissions are a prerequisite to achieving sustainable development must propel action.

The gap is so huge that governments, the private sector and communities need to switch into crisis mode, make their climate pledges more ambitious and focus on early and aggressive action. Otherwise, the Paris agreement's long-term goals are out of reach. We do not have another ten years.

\section{The authors}

Niklas Höhne is partner at NewClimate Institute, Cologne, Germany, professor for mitigation of greenhouse gases at the
University of Wageningen, the Netherlands, and affiliate at Lawrence Berkeley National Laboratory, California, USA. Michel den Elzen is a senior researcher at the PBL Netherlands Environmental Assessment Agency, The Hague, the Netherlands. Joeri Rogelj is lecturer in climate change at the Grantham Institute, Imperial College London, UK, and senior research scholar at the International Institute for Applied Systems Analysis, Laxenburg, Austria. Bert Metz is former co-chair of the IPCC Working Group on Mitigation and fellow at the European Climate Foundation, The Hague, the Netherlands. Taryn Fransen is senior fellow at the World Resources Institute, Washington DC, USA. Takeshi Kuramochi is senior climate-policy researcher at NewClimate Institute, Cologne, Germany, and affiliated with the Copernicus Institute of Sustainable Development, Utrecht University, the Netherlands. Anne Olhoff is strategic director of climate planning and policy at UNEP DTU Partnership, Technical University of Denmark, Copenhagen, Denmark. Joseph Alcamo is professor of environmental systems science and director of the Sussex Sustainability Research Programme at the University of Sussex,

\section{ACTION GAP}

Although 192 parties pledged various emissions targets under the Paris climate agreement, commitments to specific actions remain sparse*

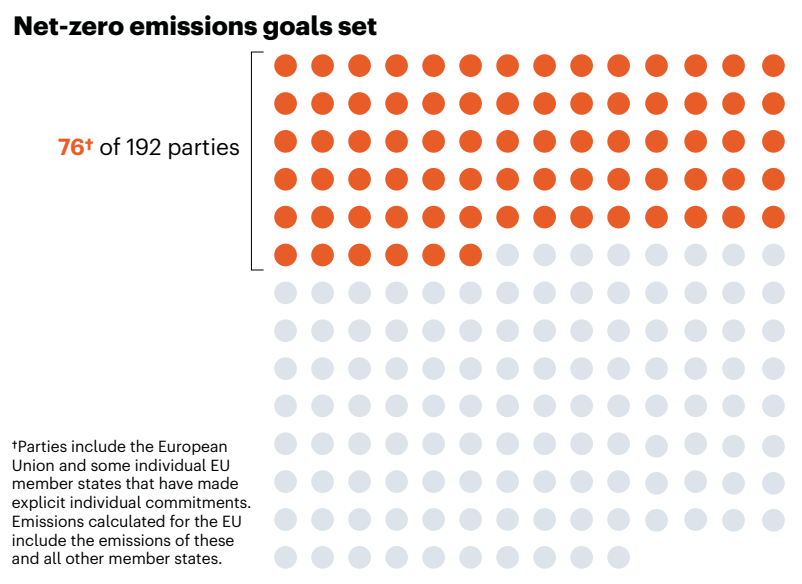

Stop fossil-fuel exploration and production 6 of 192 parties [

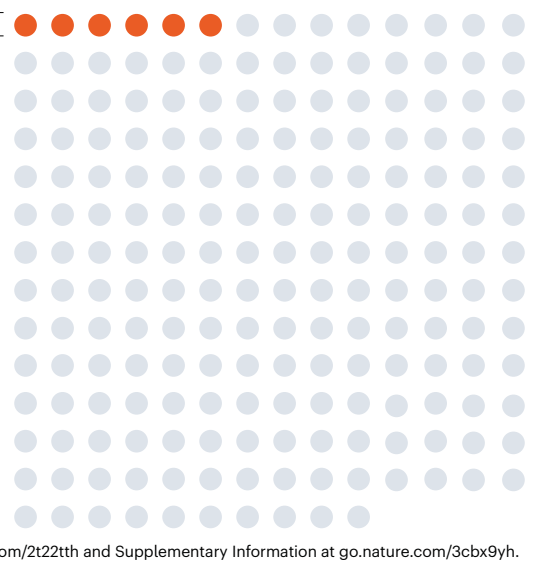

This action by 76 parties accounts for $10.2 \mathrm{GtCO}_{2}$ e of global greenhouse-gas emissions
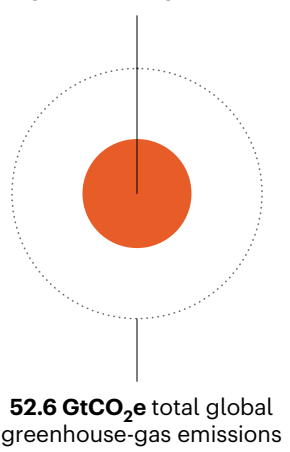

This action by 6 parties corresponds to 5 exajoules of global fossil-energy production

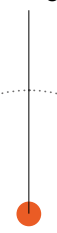

500 exajoules total global fossil-energy production
Brighton, UK. Harald Winkler is professor in energy and climate policy at the University of Cape Town, South Africa. Sha Fu is an associate professor in climate economics at Energy Foundation China, Beijing, China. Michiel Schaeffer is science director at Climate Analytics, Berlin, Germany, and affiliated with Environmental Systems Analysis Group, Wageningen University, the Netherlands. Roberto Schaeffer is professor of energy economics at the Federal University of Rio de Janeiro, Brazil. Glen P. Peters is research director at the CICERO Center for International Climate Research, Oslo, Norway. Simon Maxwell is senior research associate at the Overseas Development Institute, London, UK. Navroz K. Dubash is professor and coordinator of the Initiative on Climate, Energy and Environment at the Centre for Policy Research, New Delhi, India. e-mail: n.hoehne@newclimate.org

1. United Nations Environment Programme. The Emissions Gap Report. A Preliminary Assessment (UNEP, 2010).

2. United Nations Environment Programme. Emissions Gap Report 2019 (UNEP, 2019).

3. Rogelj, J. et al. Nature 534, 631-639 (2016).

4. Höhne, N. et al. Clim. Pol. 12, 356-377 (2011).

5. Rogelj, J. et al. Nature 464, 1126-1128 (2010).

6. Olivier, J. G. J. \& Peters, J. A. H. W. Trends in Global $\mathrm{CO}_{2}$ and Total Greenhouse Gas Emissions (PBL Netherlands Environmental Assessment Agency, 2019).

7. United Nations Framework Convention on Climate Change. Report of the Conference of the Parties on its Fifteenth Session [the Copenhagen accord 2009] (UNFCCC, 2010).

8. United Nations Framework Convention on Climate Change. Report of the Conference of the Parties on its Sixteenth Session [the Cancun agreement 2010] (UNFCCC, 2011).

9. United Nations Framework Convention on Climate Change. Report of the Conference of the Parties on its Twenty-first Session [the Paris agreement 2015] (UNFCCC, 2016).

10. Intergovernmental Panel on Climate Change. Global Warming of $1.5^{\circ} \mathrm{C}$ (IPCC, 2018).

11. Buhr, K., Roth, S. \& Stigson, P. Sustainability 6, 794-811 (2014).

12. Olivier, J. G. J. \& Peters, J. A. H. W. Trends in Global $\mathrm{CO}_{2}$ and Total Greenhouse Gas Emissions (PBL Netherlands Environmental Assessment Agency, 2018).

13. FAOSTAT. Land Use Emissions. Available at http://www. fao.org/faostat/en/\#data/GL (2019).

14. International Energy Agency. World Energy Balances (IEA, 2019).

15. International Renewable Energy Agency. Renewable Power Generation Costs in 2018 (IRENA, 2019).

16. Jewell, J., Vinichenko, V., Nacke, L. \& Cherp, A. Nature Clim. Change 9, 592-597 (2019).

17. Smouse, S. M., Jones, A., Fapohunda, B. O., Render, M. \& Hindman, J. W. in Proc. ASME 2018 Power Conference, V001T05A003 (Am. Soc. Mech. Eng., 2018).

18. Arent, D., Arndt, C., Miller, M., Tarp, F. \& Zinaman, O. (eds) The Political Economy of Clean Energy Transitions (Oxford Univ. Press, 2017).

19. Antwi-Agyei, P., Dougill, A. J., Agyekum, T. P. \& Stringer, L. C. Clim. Pol. 18, 1296-1312 (2018)

20. United Nations Environment Programme. Emissions Gap Report 2015 (UNEP, 2015).

21. International Energy Agency. World Energy Outlook 2015 (IEA, 2015).

22. International Energy Agency. World Energy Outlook 2018 (IEA, 2018).

23. Kuramochi, T. et al. Greenhouse Gas Mitigation Scenarios for Major Emitting Countries (NewClimate Institute, 2018).

24. Rochedo, P. R. R. et al. Nature Clim. Change 8, 695-699 (2018).

25. den Elzen, M. et al. Energy Pol. 126, 238-250 (2019).

Supplementary Information accompanies this article: see go.nature.com/3cbx9yh. 